\title{
Kulit Singkong (Manihot esculenta Crantz) Sebagai Karbon Aktif dengan Berbagai Langkah Pembuatan untuk Adsorpsi Ion Logam Timbal $\left(\mathbf{P b}^{2+}\right)$ dalam Air
}

\author{
Anggi Suprabawati*, Holiyah, N.W., Jasmansyah \\ Jurusan Kimia, Fakultas Sains dan Informatika, Universitas Jenderal Achmad Yani, J1. Terusan Jenderal \\ Sudirman, Cimahi, 40285 \\ *E-mail: anggi.suprabawati@lecture.unjani.ac.id
}

\begin{abstract}
Abstrak
Kulit singkong mengandung unsur karbon sebesar 59,31\% menjadi dasar penggunaan kulit singkong sebagai karbon aktif. Salah satu pemanfaatan karbon aktif untuk adsorpsi logam Pb. Pembuatan karbon aktif dilakukan dengan 3 tahap yaitu dehidrasi, karbonasi dan aktivasi. Dilakukan perbandingan karakteristik terhadap karbon aktif yang tidak teraktivasi $\mathrm{KOH}$ dan teraktivasi $\mathrm{KOH}$ dengan variasi konsentrasi yaitu 0,2 M; 0,4 M dan 0,6 M untuk mengetahui konsentrasi optimal $\mathrm{KOH}$. Pengujian karakteristik karbon aktif meliputi kadar air, kadar abu, adsorpsi iodium dan adsorpsi metilen biru serta uji adsorpsi terhadap logam $\mathrm{Pb}$. Pengukuran adsorpi logam $\mathrm{Pb}$ dilakukan menggunakan Spektroskopi Serapan Atom. Hasil penelitian menunjukkan bahwa karbon aktif yang diaktivasi dengan $\mathrm{KOH}$ 0,4 M memiliki karakteristik yang paling baik dengan hasil kadar air 3,79\%, kadar abu 8,09\%, adsorpsi iodium $863 \mathrm{mg} / \mathrm{g}$ dan adsorpsi metilen biru $3116 \mathrm{mg} / \mathrm{g}$ serta adsorpsi terhadap logam Pb sebesar 98\%.
\end{abstract}

Kata Kunci: aktivasi, karakterisasi, karbon aktif, $\mathrm{KOH}$, kulit singkong, logam $\mathrm{Pb}$

\begin{abstract}
Cassava peels contained carbon elements about $59.31 \%$, it became the base of using cassava peels as activated carbon. One of utilization of activated carbon was adsorption metal lead. Production of activated carbon was conducted in 3 steps were dehydration, carbonation and activation. Study had been conducted by comparing characteristic of activated carbon without activator and activated carbon with variation of $\mathrm{KOH}$ concentration as activator were $0.2 \mathrm{M} ; 0.4 \mathrm{M}$ and $0.6 \mathrm{M}$ so that could be known the optimal KOH concentration. Characteristic testing was conducted for water content, ash content, adsorption of iodium and adsorption of methylene blue also adsorption of lead metal. Measuring of adsorption metal lead was done by Atomic Absorption Spectroscopy. Experiment result shows activated carbon with $\mathrm{KOH} 0.4 \mathrm{M}$ has best characteristic by water content $3.79 \%$, ash content $8.09 \%$, adsorption of iodium $863 \mathrm{mg} / \mathrm{g}$ and adsorption of methylene blue $3116 \mathrm{mg} / \mathrm{g}$ also adsorption of metal lead 98\%.
\end{abstract}

Keywords: activated carbon, activation, cassava peels, characterization, $\mathrm{KOH}$, lead metal

\section{Pendahuluan}

Singkong (Manihot esculenta Crantz) merupakan tanaman yang sangat populer di seluruh dunia, khususnya di negara-negara tropis. Singkong (Manihot esculenta Crantz) merupakan salah satu bahan pangan yang utama. Di Indonesia, singkong merupakan makanan pokok ketiga setelah padi-padian dan jagung [1].

Menurut data Badan Pusat Statistik (2015), di Jawa Barat luas daerah yang digunakan untuk produksi singkong 85.288 ha [2]. Produksi singkong di Jawa Barat sebanyak 2.000.224 ton selama tahun 2015. Hasil produksi singkong selama 2015 di Provinsi Jawa Barat adalah 234,53 kwintal/ha [3]. Selama ini limbah kulit singkong belum dimanfaatkan secara maksimal oleh masyarakat setempat. Limbah tersebut digunakan untuk pakan ternak dan selebihnya dibuang karena mengandung Cyanogenic glucosides yang dapat meracuni hewan ternak [4].

Kulit singkong merupakan limbah hasil pengupasan pengolahan produk pangan berbahan dasar umbi singkong. Kulit singkong terkandung dalam setiap umbi singkong dan mencapai $16 \%$ dari berat umbi singkong tersebut.

Suprapti (2015), membuat adsorben dari kulit singkong tanpa aktivator dengan pemanasan di bawah sinar matahari memiliki efisiensi penyerapan ion logam timbal $(\mathrm{Pb}) 20,151 \%$ atau 
setara dengan adsorpsi ion logam timbal $(\mathrm{Pb})$ 2,0152 $\mathrm{mg} / \mathrm{L}$ pada kondisi $1,5 \mathrm{~g}$ adsorben dan waktu kontak 80 menit [5].

Santoso, dkk. (2014), melakukan karakterisasi terhadap karbon aktif dari kulit singkong dengan variasi konsentrasi aktivator $\mathrm{KOH}$. Konsentrasi aktivator $\mathrm{KOH}$ terbaik pada penelitian tersebut adalah konsentrasi KOH $3 \mathrm{M}$ dengan karakteristik bilangan iodin sebesar $1113,863 \mathrm{mg} / \mathrm{g}$, kadar air sebesar 6,349\%, kadar abu sebesar 9,217\% serta densitas sebesar $0,951 \mathrm{~g} / \mathrm{mL}$ [6]. Keefektifan karbon aktif dari kulit singkong cocok digunakan sebagai adsorben untuk pengolahan air limbah [7].

Menurut Sahira (2013) dalam penelitiannya melakukan pembuatan karbon aktif dari bahan baku Lapsi Seed Stone menggunakan berbagai aktivator, diantaranya $\mathrm{FeCl}, \mathrm{MgCl}_{2} \mathrm{CaCl}_{2}, \mathrm{H}_{2} \mathrm{SO}_{4}$ dan $\mathrm{KOH}$. Dari hasil karakterisasi diketahui bahwa karbon aktif yang teraktivasi oleh $\mathrm{KOH}$ memiliki luas permukaan dan porositas yang paling baik dibandingkan dengan karbon aktif dengan aktivator lain [8]. Kemudian pada penelitian Sudibandriyo dan Lydia (2011), dikatakan bahwa aktivator yang lebih baik digunakan untuk pembuatan karbon aktif dari ampas tebu dengan metode aktivasi kimia ialah $\mathrm{KOH}$ dibandingkan $\mathrm{ZnCl}_{2}$ [9].

Timbal $(\mathrm{Pb})$ merupakan salah satu logam berat yang dapat mencemari lingkungan. Sumber masuknya $\mathrm{Pb}$ ke perairan berasal dari limbah industri seperti industri baterai, kabel, cat atau pewarna, industri keramik dan gas buang kendaraan [10]. Pencemaran $\mathrm{Pb}$ di perairan yang melebihi konsentrasi ambang batas dapat menyebabkan kematian bagi biota perairan tersebut [11]. Menurut peraturan pemerintah Nomor 82 Tahun 2001, kadar maksimum cemaran timbal dalam perairan sebesar $0,03 \mathrm{ppm}$ [12]. Oleh karena itu, penelitian ini akan dilakukan pembuatan karbon aktif dari kulit singkong yang tidak teraktivasi $\mathrm{KOH}$ dan karbon aktif yang diaktivasi dengan variasi konsentrasi $\mathrm{KOH}$ yaitu 0,2 M; 0,4 M dan 0,6 M untuk mengetahui karakteristik karbon aktif dan sebagai adsorben ion logam $\mathrm{Pb}$

\section{Metode Penelitian}

\subsection{Pembuatan Karbon Aktif}

1) Tahap Dehidrasi

Kulit singkong dipotong-potong sepanjang 2 $\mathrm{cm}$. Kemudian dipanaskan di dalam oven pada suhu $100{ }^{\circ} \mathrm{C}$ selama 1 jam hingga bahan baku kering atau hilang kadar airnya.

\section{2) Tahap Karbonasi}

Kulit singkong dalam keadaan kering dibakar di dalam furnace selama $1 \mathrm{jam}$ pada suhu $500{ }^{\circ} \mathrm{C}$. Arang yang dihasilkan tersebut digiling. Kemudian dilakukan pengayakan dengan ukuran 100 mesh. Didapatkan sampel karbon aktif tanpa aktivator.

\section{3) Tahap Aktivasi}

Arang direndam di dalam larutan aktivator $\mathrm{KOH}$ dengan variasi konsentrasi $0,2 \mathrm{M}$; 0,4 M; 0,6 M selama 24 jam. Dari langkah di atas didapat sampel pasta arang. Sampel pasta arang disaring dengan kertas saring, kemudian dicuci dengan aquadest hingga $\mathrm{pH}$ 7. Sampel dikeringkan dalam oven pada suhu $150{ }^{\circ} \mathrm{C}$ selama 2 jam. Didapatkan tiga macam sampel dengan konsentrasi aktivator yang berbeda.

\subsection{Karakterisasi Karbon Aktif}

\section{1) Kadar Air (SNI 06-4253-1996)}

Sebanyak 1 gram karbon aktif masukkan ke dalam cawan porselen yang sudah diketahui bobotnya. Cawan yang berisi karbon aktif dimasukkan ke dalam oven yang telah diatur suhunya $\pm 105^{\circ} \mathrm{C}$ selama 3 jam. Karbon aktif didinginkan di dalam desikator dan ditimbang beratnya. Penentuan kadar air dihitung dengan persamaan 1 .

kadar air $(\%)=\frac{W_{1}-W_{2}}{W_{1}} \times 100 \%$

Keterangan:

$\mathrm{W}_{1}=$ Bobot sampel sebelum pemanasan $(\mathrm{g})$

$\mathrm{W}_{2}=$ Bobot sampel setelah pemanasan $(\mathrm{g})$

2) Kadar Abu (SNI 06-4253-1996)

Sebanyak 1 gram karbon aktif ditimbang dan dimasukkan ke dalam cawan krus yang sudah diketahui bobotnya. Cawan krus yang sudah diisi dan ditimbang, dimasukkan ke dalam tungku pada suhu $750{ }^{\circ} \mathrm{C}$ selama 6 jam. Abu didinginkan dalam desikator selama 15 menit kemudian ditimbang beratnya. Kadar abu dihitung menggunakan persamaan 2 .

kadar abu $(\%)=\frac{B T}{B A} \times 100 \%$

Keterangan:

$\mathrm{BA}=$ Berat sampel awal

$\mathrm{BT}=$ Berat abu total 
3) Adsorpsi sampel terhadap Iodium (SNI 064253-1996)

Karbon aktif dipanaskan di dalam oven pada suhu $105^{\circ} \mathrm{C}$ selama 1 jam. Sebanyak $0,5 \mathrm{~g}$ karbon aktif diambil, lalu ditambahkan $50 \mathrm{~mL}$ larutan Iodium $0,1 \mathrm{~N}$ dan diaduk selama 15 menit serta disentrifugal selama 15 menit. Kemudian diambil $10 \mathrm{~mL}$ filtrat dan dititrasi dengan menggunakan larutan natrium tiosulfat $0,1 \mathrm{~N}$.

Jika warna kuning telah samar dilakukan penambahan $1 \mathrm{~mL}$ larutan amilum $1 \%$ sebagai indikator. Proses titrasi diulang kembali hingga warna biru hilang. Daya serap $(\mathrm{mg} / \mathrm{g})$ dihitung menggunakan persmaan 3 .

$$
\text { Daya Serap }=\frac{\left(V_{1}-\left(V_{2} \times N_{2}\right)\right.}{N_{1}} \times 126,93 \times f_{p} \times \frac{1}{w}
$$

\section{Keterangan:}

$\mathrm{V}_{1} \quad=$ Volume iodium $(\mathrm{mL})$

$\mathrm{N}_{1} \quad=$ Konsentrsi iodium $(\mathrm{N})$

$\mathrm{V}_{2} \quad=$ Volume $\mathrm{Na}_{2} \mathrm{~S}_{2} \mathrm{O}_{3}(\mathrm{~mL})$

$\mathrm{N}_{2}=$ Konsentrasi $\mathrm{Na}_{2} \mathrm{~S}_{2} \mathrm{O}_{3}(\mathrm{~N})$

$126,93=$ Jumlah iodin sesuai $1 \mathrm{~mL}$ larutan $\mathrm{Na}_{2} \mathrm{~S}_{2} \mathrm{O}_{3}$

$\mathrm{f}_{\mathrm{p}} \quad=$ Faktor pengenceran

$\mathrm{W} \quad=$ massa karbon aktif $(\mathrm{g})$

4) Adsorpsi sampel terhadap larutan metilen biru (SNI 06-4253-1996)

Karbon aktif dipanaskan di dalam oven pada suhu $105{ }^{\circ} \mathrm{C}$ selama 1 jam. Diambil masingmasing karbon aktif sebanyak 0,5 g kemudian dimasukkan ke dalam erlenmeyer. Pada setiap sampel ditambahkan metilen biru $75 \mathrm{mg} / \mathrm{L}$ sebanyak $50 \mathrm{~mL}$. Kemudian dikocok menggunakan magnetic stirrer selama 15 menit dengan kecepatan 100 rpm. Larutan sampel pada bagian yang bening dipipet dan diukur absorbansi menggunakan spektrofotometri UV-Vis pada panjang gelombang yang telah ditentukan sebelumnya. Adsorpsi metilen biru (MB) dihitung menggunakan persamaan 4 .

$$
\text { Adsorpsi } M B=\frac{\left(X_{0}-X_{1}\right)}{W} \times V \times W
$$

Keterangan:

$\mathrm{X}_{0}=$ Konsentrasi awal $(\mathrm{mg} / \mathrm{L})$

$\mathrm{X}_{1}=$ konsentrasi akhir $(\mathrm{mg} / \mathrm{L})$
$\mathrm{V}=$ volume larutan $(\mathrm{L})$

$\mathrm{W}=$ Berat sampel $(\mathrm{g})$

5) Uji Daya Adsorpsi Karbon Aktif terhadap Logam $\mathrm{Pb}$

Karbon aktiff ditimbang 1,5 g kemudian dimasukkan ke dalam $15 \mathrm{~mL}$ larutan baku $\mathrm{Pb} 10$ $\mathrm{mg} / \mathrm{L}$. Campuran dikocok dengan magnetic stirrer selama kurang lebih 5 menit untuk menghomogenkan campuran. Campuran didiamkan selama 24 jam. Kemudian campuran disaring dan filtrat dianalisa dengan AAS.

\section{Hasil dan Diskusi}

\subsection{Pembahasan Pembuatan Karbon Aktif}

Sebelum dibuat diproses untuk menjadi karbon aktif, terlebih dahulu kulit singkong dibersihkan dan dicuci untuk menghilangkan pengotor. Kemudian kulit singkong dipotong kecil $2 \mathrm{~cm}$ untuk memperkecil ukuran. Kulit singkong yang sudah dipotong kecil kemudian dilakukan proses dehidrasi dengan dipanaskan dalam oven pada suhu $105{ }^{\circ} \mathrm{C}$ selama 1 jam. Proses dehidrasi ini bertujuan untuk menghilangkan kadar air. Kandungan air dalam kulit singkong berkisar 7,9 $-10,32 \%$ [13].

Selanjutnya dilakukan proses karbonasi kulit singkong di dalam furnace pada suhu $500{ }^{\circ} \mathrm{C}$ selama 1 jam. Arang hasil karbonasi dihaluskan dan diayak menggunakan ayakan mesh 100. Dengan proses penghalusan, proses aktivasi kimia akan lebih merata karena semakin kecil ukuran arang karbonasi kulit singkong, maka semakin besar luas permukaan yang akan terkena kontak dengan aktivator sehingga lebih banyak karbon yang teraktivasi dan semakin banyak pori-pori yang terbentuk pada setiap partikel karbon.

Arang hasil karbonasi yang sudah halus, diaktivasi menggunakan larutan $\mathrm{KOH}$ dengan variasi konsentrasi $0,2 \mathrm{M}$; 0,4 $\mathrm{M}$; dan 0,6 $\mathrm{M}$. Karbon aktif direndam dengan $100 \mathrm{~mL}$ larutan aktivator dan didiamkan selama 24 jam. Selanjutnya karbon aktif disaring dan dicuci dengan aquades hingga $\mathrm{pH}$ netral sehingga diperoleh pasta arang. Karbon aktif yang sudah netral dikeringkan dengan dimasukkan dalam oven pada suhu $105^{\circ} \mathrm{C}$ selama 2 jam. 
Tabel 1. Karakteristik Karbon Aktif dan Adsorpsi Ion Logam Timbal (Pb)

\begin{tabular}{cccccc}
\hline Karbon Aktif & $\begin{array}{c}\text { Kadar Air } \\
(\%)\end{array}$ & $\begin{array}{c}\text { Kadar Abu } \\
(\%)\end{array}$ & $\begin{array}{c}\text { Adsorpsi } \\
\text { Iodium }(\mathrm{mg} / \mathrm{g})\end{array}$ & $\begin{array}{c}\text { Adsorpsi } \\
\text { Metilen Biru } \\
(\mathrm{mg} / \mathrm{g})\end{array}$ & $\begin{array}{c}\text { Adsorpsi ion } \\
\text { logam timbal } \\
(\mathrm{Pb})\end{array}$ \\
\hline AC non KOH & 1,51 & 5,57 & 609 & 621 & $89 \%$ \\
AC 0,2 M & 2,18 & 6,38 & 749 & 1903 & $97 \%$ \\
AC 0,4 M & 3,79 & 8,09 & 863 & 3116 & $98 \%$ \\
AC 0,6 M & 3,26 & 13,95 & 711 & 1019 & $97 \%$ \\
\hline
\end{tabular}

\subsection{Hasil Karakterisasi Karbon Aktif}

\section{1) Kadar Air}

Penentuan kadar air bertujuan untuk mengetahui sifat higroskopis dari karbon aktif, dimana umumnya karbon aktif memiliki sifat afinitas yang sangat besar terhadap air [14]. Penentuan kadar air dilakukan dengan menimbang sebanyak 1 gram karbon aktif kemudian masukan ke dalam cawan porselen yang sudah diketahui bobotnya. Cawan yang berisi karbon aktif dimasukkan ke dalam oven yang telah diatur suhunya $\pm 105^{\circ} \mathrm{C}$ selama 3 jam. Kemudian karbon aktif didinginkan di dalam desikator dan ditimbang beratnya.

Dari data penelitian pada Tabel 1 . menunjukkan bahwa kadar air yang diperoleh berkisar antara $1,51-3,79 \%$. Berdasarkan data pada tabel 1., bahwa kadar air paling kecil yaitu $1,51 \%$ untuk karbon aktif tanpa aktivator, sedangkan kadar air paling tinggi yaitu 3,79\% untuk karbon aktif dengan aktivator $\mathrm{KOH} \mathrm{0,4} \mathrm{M.}$ sedangkan kadar air untuk karbon aktif dengan $\mathrm{KOH} 0,2 \mathrm{M}$ adalah 2,18\% dan karbon aktif dengan $\mathrm{KOH}$ 0,6 M adalah 3,26\%.

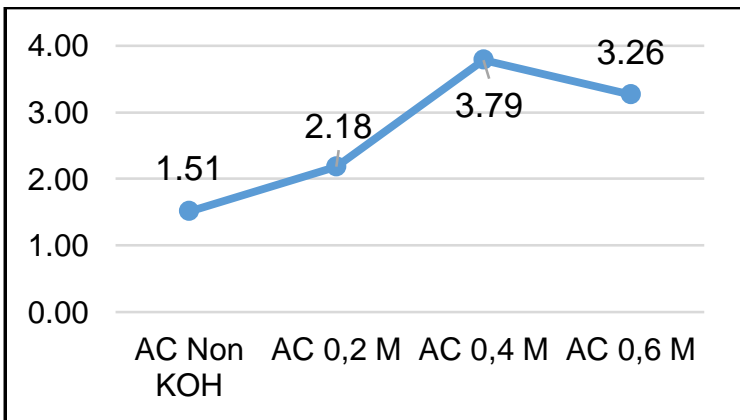

Gambar 1. Grafik pengaruh konsentrasi $\mathrm{KOH}$ terhadap kadar air karbon aktif

Gambar 1 menunjukkan bahwa semakin tinggi konsentrasi aktivator yang digunakan akan meningkatkan kadar air. Aktivator berperan penting untuk meningkatkan luas permukaan adsorben dengan cara mengurangi senyawa non karbon dari pori-pori. Hal ini mengakibatkan semakin tinggi konsentrasi aktivator maka semakin besar dan banyak pori-pori yang terbentuk sehingga luas permukaan karbon aktif semakin meningkat. Semakin luas permukaan karbon aktif tersebut akan meningkatkan sifat higroskopis, sehingga penyerapan air dari udara oleh karbon aktif akan semakin meningkat, akibatnya kadar air pada karbon aktif tersebut juga meningkat [15].

\section{2) Kadar Abu}

Penentuan kadar abu bertujuan untuk mengetahui kandungan sisa mineral dalam arang aktif yang tidak terbuang saat karbonasi dan aktivasi. Mineral yang masih tersisa akan menyebabkan terjadinya penyumbatan pori-pori arang aktif sehingga mempengaruhi adsorpsi yang terjadi [16]. Kandungan abu sangat berpengaruh pada kualitas karbon aktif. Keberadaan abu yang berlebihan dapat menyebabkan terjadinya penyumbatan pori-pori karbon aktif, sehingga luas permukaan karbon aktif menjadi berkurang. Penentuan kadar abu dilakukan dengan karbon aktif ditimbang sebanyak 1 gram dan dimasukkan ke dalam cawan krus yang sudah diketahui bobotnya. Cawan krus yang sudah diisi dan ditimbang, dimasukkan ke dalam furnace pada suhu $750^{\circ} \mathrm{C}$ selama 6 jam. Abu didinginkan dalam desikator selama 15 menit kemudian ditimbang beratnya.

Dari Tabel 1 dapat dilihat bahwa kadar abu karbon aktif pada penelitian terendah adalah 5,57\% pada karbon aktif tanpa aktivator, hal ini karena pada karbon aktif tidak ditambah aktivator sehingga tidak ada peningkatan kandungan mineral dalam karbon aktif. Pada kulit singkong sendiri sudah mengadung mineral $\mathrm{Ca}$ sebanyak $0,42-0,77 \%$ dan $\mathrm{Mg}$ sebanyak $0,12-0,24 \%$ [13]. Sedangkan kadar abu tertinggi adalah 13,95\% pada karbon aktif dengan aktivator $\mathrm{KOH} \mathrm{0,6} \mathrm{M.}$ Kadar abu untuk karbon aktif dengan $\mathrm{KOH} \mathrm{0,2}$ adalah 6,38\% dan kadar abu dengan $\mathrm{KOH}$ 0,6 M adalah $13,95 \%$. 


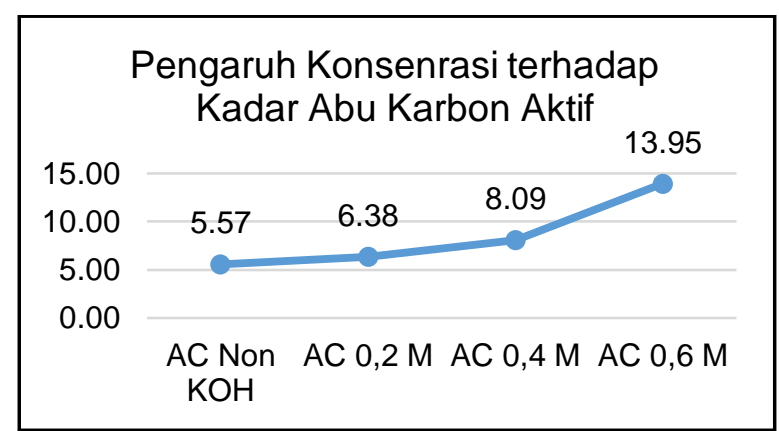

Gambar 2. Grafik pengaruh konsentrasi KOH terhadap kadar abu karbon aktif.

Gambar 2. menunjukkan adanya pengaruh konsentrasi aktivator terhadap kadar abu pada karbon aktif. Dari data penelitian diperoleh, semakin tinggi konsentrasi $\mathrm{KOH}$ maka semakin tinggi pula kadar abu. Hal ini disebabkan semakin tinggi konsentrasi aktivator, semakin banyak mineral dari aktivator yang masih tertinggal pada karbon aktif [6].

\section{3) Adsorpsi Iodium}

Adsorpsi iodium dinyatakan dalam satuan $\mathrm{mg} / \mathrm{g}$, hal tersebut menyatakan jumlah iodium (mg) yang mampu diadsorpsi oleh satu gram karbon aktif. Daya adsorpsi karbon aktif terhadap iodium menandakan kemampuan karbon aktif untuk mengadsorpsi partikel-partikel dengan ukuran molekul yang lebih kecil. Penentuan daya serap terhadap iodium bertujuan untuk mengetahui kemampuan karbon aktif untuk menyerap larutan berwarna dengan ukuran molekul kurang dari $10 \AA$ atau $1 \mathrm{~nm} \mathrm{[17].}$ Penenruan adsorpsi iodium dilakukan dengan pemanasan karbon aktif di dalam oven pada suhu $105^{\circ} \mathrm{C}$ selama 1 jam. Kemudian sebanyak 0,5 g karbon aktif diambil, lalu ditambahkan $50 \mathrm{~mL}$ larutan Iodium $0,1 \mathrm{~N}$ dan diaduk selama 15 menit serta disentrifugal selama 15 menit. Kemudian diambil $10 \mathrm{~mL}$ filtrat dan dititrasi dengan menggunakan larutan natrium tiosulfat $0,1 \mathrm{~N}$. Ketika warna kuning telah samar dilakukan penambahan $1 \mathrm{~mL}$ larutan amilum $1 \%$ sebagai indikator. Proses titrasi diulang kembali hingga warna biru hilang.

Tabel 1 menunjukkan karbon aktif tanpa aktivator menunjukkan adsorpsi iodium yang paling rendah yaitu $609 \mathrm{mg} / \mathrm{g}$ hal ini dikarenakan proses pembukaan pori-pori kurang maksimal tanpa bantuan aktivator. Selanjutnya terjadi kenaikan adsorpsi iodium pada karbon aktif dengan $\mathrm{KOH} \mathrm{0,2} \mathrm{M} \mathrm{yaitu} \mathrm{sebersar} 749 \mathrm{mg} / \mathrm{g}$, karbon aktif dengan $\mathrm{KOH} \mathrm{0,4} \mathrm{M} \mathrm{yaitu} \mathrm{sebesar} 863$ $\mathrm{mg} / \mathrm{g}$. Namun pada karbon aktif dengan KOH 0,6 $\mathrm{M}$ terjadi penurunan yaitu $711 \mathrm{mg} / \mathrm{g}$. Meskipun terjadi penurunan namun jika dibandingkan dengan karbon aktif tanpa aktivator $\mathrm{KOH}$, adsorpsi iodium karbon aktif dengan $\mathrm{KOH}$ 0,6 M lebih tinggi, Hal ini menunjukkan bahwa penggunaan aktivator memberi pengaruh terhadap pori-pori karbon aktif yang dihasilkan.

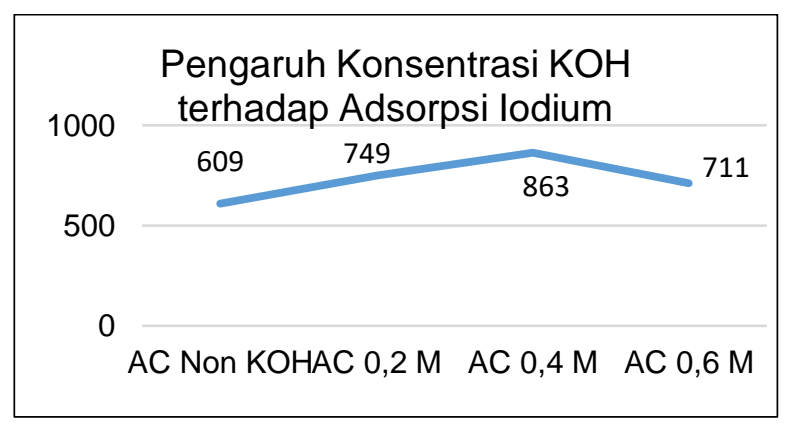

Gambar 3. Grafik Pengaruh Konsentrasi Aktivator terhadap Adsorpsi Iodium

Gambar 3 menunjukkan bahwa pengaruh konsentrasi $\mathrm{KOH}$ terhadap adsorpsi iodium menunjukan peningkatan. Menurut Santoso, dkk. (2014), bilangan iodin tersebut menunjukkan bahwa konsentrasi $\mathrm{KOH}$ memberikan pengaruh terhadap terbukanya pori-pori karbon aktif pada saat aktivasi [6]. Semakin tinggi konsentrasi $\mathrm{KOH}$ yang diberikan, maka semakin banyak pori-pori yang terbentuk.

Tinggi rendahnya daya serap arang aktif terhadap iodium menunjukkan jumlah pori mikropori yang terbentuk pada arang aktif. Semakin tinggi daya serap iodium maka semakin banyak mikropori yang terbentuk pada arang aktif [18].

\section{4) Adsorpsi Metilen Biru}

Uji adsorpsi metilen biru bertujuan untuk mengetahui kemampuan arang aktif untuk menyerap larutan berwarna dan menentukan luas permukaan pori karbon aktif. Penetapan daya serap metilen biru bertujuan untuk mengetahui kemampuan arang aktif dalam mengadsorpsi zatzat yang berukuran besar berkisar 15-25 Angstrom atau 1,5-2,5 nm [18]. Oleh karenanya kemampuan mengadsorpsi metilen biru menjadi salah satu ukuran kualitas dari metilen blue yang dihasilkan di mana SNI mensyaratkan kemampuan minimal menyerap adalah $120 \mathrm{mg} / \mathrm{g}$ untuk serbuk karbon aktif [19].

Metilen biru merupakan molekul yang memiliki ukuran cukup besar, sehingga dapat digunakan untuk menentukan ukuran pori karbon aktif. Menurut Jankowska (1991), menyatakan bahwa semua prosedur tentang pembuatan karbon aktif yang bertujuan untuk membuka pori-pori 
karbon, akan sangat tergantung pada konsentrasi zat aktivator. Semakin tinggi konsentrasi aktivator akan menyebabkan semakin banyak zat pengotor yang berupa zat organik maupun anorganik melarut dan lepas dari permukaan pori-pori karbon, sehingga akan menyebabkan peningkatan daya serap [20].

Penentuan adsoprsi metilen biru dilakukan dengan terlebih dahulu dilakukan pemanasan karbon aktif di dalam oven pada suhu $105{ }^{\circ} \mathrm{C}$ selama 1 jam. Diambil masing-masing karbon aktif sebanyak 0,5 g kemudian dimasukkan ke dalam Erlenmeyer. Pada setiap sampel ditambahkan metilen biru $75 \mathrm{mg} / \mathrm{L}$ sebanyak 50 $\mathrm{mL}$. Kemudian dikocok menggunakan magnetic stirrer selama 15 menit dengan kecepatan 100 rpm. Larutan sampel pada bagian yang bening dipipet dan diukur absorbansi menggunakan spektrofotometri UV-Vis pada panjang gelombang yang telah ditentukan sebelumnya. Penentuan panjang gelombang maksimal metilen biru dilakukan dengan mengukur larutan metilen biru 2 ppm kemudian diukur pada panjang gelombang $600 \mathrm{~nm}-700 \mathrm{~nm}$.

Tabel 1 menjelaskan bahwa berat metilen biru teradsorpsi menunjukkan nilai yang berbedabeda pada masing-masing karbon aktif tanpa aktivator $\mathrm{KOH}$ dan karbon aktif dengan variasi konsentrasi aktivator $\mathrm{KOH}$. Dari hasil adsorpsi diketahui bahwa dengan kenaikan konsentrasi $\mathrm{KOH}$ maka kemampuan adsorpsi semakin tinggi. Kemampuan mengadsorpsi tertinggi ada pada karbon aktif dengan $\mathrm{KOH} \mathrm{0,4} \mathrm{M.}$

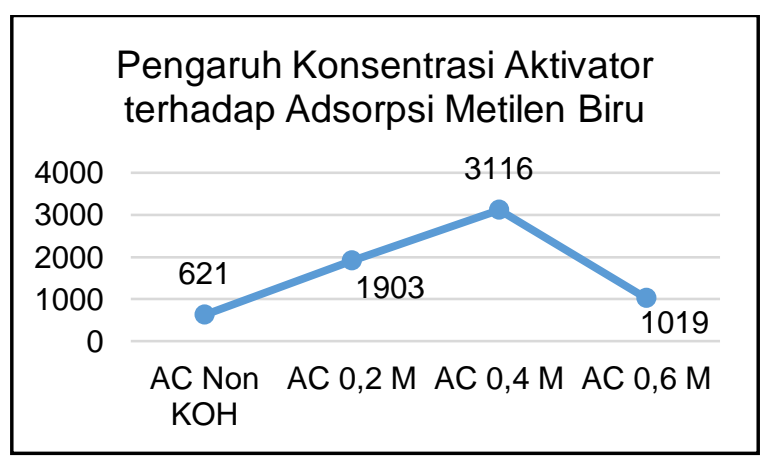

Gambar 4. Grafik Pengaruh Konsentrasi Aktivator terhadap Adsorpsi Metilen Biru

Pada Gambar 4, hasil menunjukkan bahwa karbon aktif yang tidak diaktivasi menggunakan $\mathrm{KOH}$ menunjukkan hasil daya adsorpsi terkecil yaitu $621 \mathrm{mg} / \mathrm{g}$ dibandingkan dengan karbon aktif lain yang diaktivasi $\mathrm{KOH}$. Kemampuan adsorpsi akan meningkat dari karbon aktif dengan $\mathrm{KOH} 0,2$ M yaitu $1903 \mathrm{mg} / \mathrm{g}$ dan karbon aktif dengan $\mathrm{KOH}$ $0,4 \mathrm{M}$ sebesar $3116 \mathrm{mg} / \mathrm{g}$. Namun terjadi penurunan pada karbon aktif dengan $\mathrm{KOH}$ 0,6 M yaitu $1019 \mathrm{mg} / \mathrm{g}$.

Aktivator kimia umumnya berfungsi sebagai bahan pengaktif yang berfungsi untuk mendegradasi atau penghidrasi molekul organik selama proses karbonisasi, membatasi pembentukan tar, membantu dekomposisi senyawa organik pada aktivasi berikutnya, dehidrasi air yang terjebak dalam rongga-rongga karbon, membantu menghilangkan endapan hidrokarbon yang dihasilkan saat proses karbonisasi dan melindungi permukaan karbon sehingga kemungkinan terjadinya oksidasi dapat dikurangi [21].

Menurut Prasetyo dkk., (2011), dalam penelitian pembuatan karbon aktif dari ban bekas menggunakan $\mathrm{NaCl}$ sebagai aktivator. $\mathrm{NaCl}$ sebagai aktivator kimia mampu menekan pengotor hidrokarbon dan pengotor dalam pori karbon aktif menyebabkan semakin besar volume pori, selain itu $\mathrm{NaCl}$ mampu menghidrasi kandungan air yang ada dalam pori sehingga volume pori semakin besar [19]. Dari penelitian didapatkan hasil bahwa semakin tinggi konsentrasi $\mathrm{NaCl}$ maka daya adsorpsi semakin tinggi, hal ini menunjukkan bahwa pori karbon aktif semakin besar sehingga kemampuan mengadsorpsi juga semakin besar. Akan tetapi $\mathrm{NaCl}$ yang berlebih menyebabkan $\mathrm{NaCl}$ sulit keluar dari pori karbon sehingga akan mempersempit volume pori karbon aktif.

Hal ini juga terjadi pada penelitian yang dilakukan. Karbon aktif dengan konsentrasi $\mathrm{KOH}$ yang tinggi memiliki kemampuan adsorpsi metilen blue yang paling rendah dibandingkan dengan karbon aktif $\mathrm{KOH} \mathrm{0,2} \mathrm{M}$ dan karbon aktif dengan $\mathrm{KOH}$ 0,4 M. Ini disebabkan karena pada konsentrasi $\mathrm{KOH}$ 0,6 $\mathrm{M}$ telah terjadi keadaan jenuh (kandungan $\mathrm{KOH}$ berlebih di permukaan karbon aktif) sehingga menghalangi proses penyerapan metilen biru.

\subsection{Uji Daya Adsorpsi Karbon Aktif terhadap Logam $\mathrm{Pb}$.}

Pada penelitian ini diperoleh dua jenis karbon aktif yaitu karbon aktif tanpa aktivator dan karbon aktif dengan aktivator $\mathrm{KOH}$, sehingga dapat diketahui pengaruh aktivator dan konsentrasi aktivator terhadap daya serap karbon aktif. 


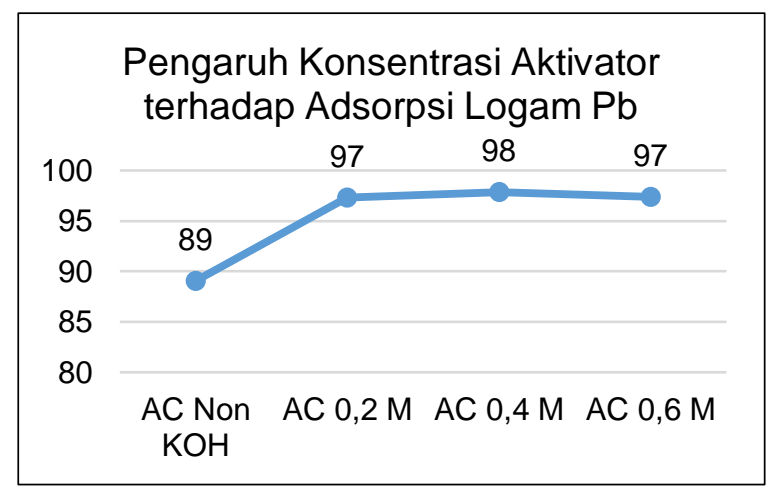

Gambar 5. Grafik Pengaruh Konsentrasi Aktivator terhadap Adsorpsi Logam $\mathrm{Pb}$

Gambar 5 menunjukkan pengaruh aktivator dan konsentrasi aktivator terhadap daya serap karbon aktif. Karbon aktif tanpa aktivator memiliki daya serap yang paling rendah dibandingkan dengan karbon aktif yang menggunakan aktivator KOH. Namun demikian karbon aktif tanpa aktivator memiliki daya serap meskipun tidak teraktivasi secara kimia dengan penambahan $\mathrm{KOH}$ namun pada saat karbonasi pori-pori terbentuk akibat pemanasan dengan hilangnya volatile matter sehingga terbentuk rongga.

Karbon aktif tanpa $\mathrm{KOH}$ memiliki daya serap ion logam $\mathrm{Pb}^{2+}$ paling kecil dibandingkan dengan karbon aktif dengan aktivator $\mathrm{KOH}$ yaitu $89 \%$. Karbon aktif dengan $\mathrm{KOH}$ 0,2 M memiliki daya serap ion logam $\mathrm{Pb}^{2+} \quad 97 \%$ lebih kecil dibandingkan dengan karbon aktif dengan $\mathrm{KOH}$ $0,4 \mathrm{M}$ yang memiliki daya serap ion logam $\mathrm{Pb}^{2+}$ sebesar 98\%. Hal ini menunjukkan bahwa semakin tinggi konsentrasi aktivator maka akan meningkatkan daya serap karbon aktif. Namun terjadi penurunan pada karbon aktif dengan $0,6 \mathrm{M}$ yang memiliki daya serap terhadap ion logam $\mathrm{Pb}^{2+}$ yaitu $97 \%$. Hal ini diperkuat dengan pernyataan Khairunisa (2008) yang mengemukakan bahwa semakin besar konsentrasi dan ukuran adsorbat maka pori-pori karbon aktif akan lebih cepat jenuh [22].

\section{Kesimpulan}

Karbon aktif yang diaktivasi $\mathrm{KOH} 0,4 \mathrm{M}$ menunjukkan karakteristik yang paling baik diantara karbon aktif yang diaktivasi $\mathrm{KOH} 0,2 \mathrm{M}$ dan 0,6 M dengan kadar air 3,79\%, kadar abu $8,09 \%$, adsorpsi iodium $863 \mathrm{mg} / \mathrm{g}$ dan adsorpsi metilen biru $3116 \mathrm{mg} / \mathrm{g}$, serta adsorpsi ion logam $\mathrm{Pb}^{2+}$ sebesar $98 \%$.

Sedangkan karbon aktif tanpa aktivator menunjukkan hasil yang paling rendah dibandingkan dengan karbon aktif teraktivasi $\mathrm{KOH}$ dilihat dari hasil uji karakterisasi yaitu kadar air $1,51 \%$, kadar abu $5,57 \%$, adsorpsi iodium $609 \mathrm{mg} / \mathrm{g}$, adsorpsi metilen biru $621 \mathrm{mg} / \mathrm{g}$ dan uji adsorpsi ion logam $\mathrm{Pb} 2+89 \%$.

\section{Ucapan Terima Kasih}

Penulis ucapkan terima kasih kepada pihak yang telah membantu selama pelaksanaan penelitian, yaitu Laboratorium Kimia Fakultas Matematika dan Ilmu Pengetahuan Alam Universitas Jenderal Achmad Yani, Cimahi.

\section{Daftar Pustaka}

[1] Chalil, D, 2003, Agribisnis Ubi Kayu di Propinsi Sumatera Utara. Jurusan Sosial Ekonomi Pertanian, Fakultas Pertanian, Universitas Sumatera Utara, Medan.

[2] Badan Pusat Statistik (BPS), 2015, Luas Daerah Produksi Ubi Kayu Propinsi Jawa Barat.

[3] Badan Pusat Statistik (BPS), 2015, Produktivitas Ubi Kayu Propinsi Jawa Barat.

[4] Nursita, 2005, Sifat Fisik dan Palabilitas Wafe Ransum Komplit untuk Domba dengan Menggunakan Kulit Singkong, Skripsi, Departemen Ilmu Nutrisi dan Makanan Ternak, Fakultas Peternakan, Institut Pertanian Bogor.

[5] Suprapti, A., Bakri, B., Rahmanita, N., 2015, Pemanfaatan Kulit Singkong Untuk Mengadsorpsi Ion Logam Timbal (Pb). Jurusan Teknik Sipil, Universitas Hasanuddin, Makassar 90245, Indonesia FMIPA.

[6] Santoso, R.H., Susilo, B. Nugroho, W.A., 2014, Pembuatan dan Karakterisasi Karbon Aktif dari Kulit Singkong (Manihot esculenta Crantz) Menggunakan Activating Agent $\mathrm{KOH}$, Jurnal Keteknikan Pertanian Tropis dan Biosistem, Vol. 2, No.3, Hlm. 279-286.

[7] IIlaboya, I.R., Oti, E.O., Ekoh, G.O., Umukoro, L.O., 2013, Performance of Activated Carbon from Cassava Peels for the Treatment of Effluent Wastewater, Iranica Journal of Energy \& Environment, 4 (4): 361-375.

[8] Sahira, J., Mandira, A., Prasad, P.B., Ram, P.R., 2013, Effects of Activating Agents on the Activated Carbons Prepared from Lapsi Seed Stone, Research Journal of Chemical Sciences, 3, (5), 19-24. 
[9] Sudibandriyo, Mahmut, Lydia, 2011, Karakteristik Luas Permukaan Karbon Aktif Dari Ampas Tebu Dengan Aktivasi Kimia, Penerbit FT Kimia UI, Jakarta.

[10] Sudarmadji, Mukono, J., dan Corie, I.P., 2006, Toksikologi Logam Berat B3 dan Dampaknya terhadap Kesehatan. Jurnal Kesehatan Lingkungan, 2:129-142.

[11] Suharto, 2005, Dampak pencemaran logam Timbal $(\mathrm{Pb})$ terhadap kesehatan masyarakat. Majalah Kesehatan Indonesia No. 165. Universitas Airlangga, Surabaya.

[12] Peraturan Pemerintah Republik Indonesia Nomor 82 Tahun 2001, Pengelolaan Kualitas Air dan Pengendalian Pencemaran Air, Pemerintah Republik Indonesia, Jakarta.

[13] Richana, N., 2013, Mengenai Potensi Ubi Kayu \& Ubi Jalar, Nuansa Cendikia : Bandung.

[14] Maulinda, L., Nasrul Z.A., Sari, D.N., 2015, Pemanfaatan Kulit Singkong sebagai Bahan Baku Karbon Aktif, Jurnal Teknologi Kimia Unimal, 4:2, 11-19.

[15] Subadra, Indah, dkk., 2005, Activated Carbon Production From Coconut Shell With $\left(\mathrm{NH}_{4}\right) \mathrm{HCO}_{3}$ Activator as an Adsorbent in Virgin Coconut Oil Purification, Physical Chemistry Laboratory, UGM.

[16] Harlendien, Y. L., 2013. Pemanfaatan Arang Aktif sebagai Adsorben Logam Berat dalam Air Lindi di TPA Pakusari Jember,
Universitas Jember, Fakultas MAtematika dan Ilmu Pengetahuan Alam.

[17] Kurniawan, I. K. G. I., 2010, Pembuatan dan Pemanfaatan Karbon Aktif dari Tempurung Buah Lontar (Borassus flabelliferlinn) Sebagai Adsorben Limbah Batuk Kayu, UGM, 476-484.

[18] Achmad, A., 2001, Pembuatan, Pencirian dan Uji Daya Adsorpsi Arang Aktif dari Kayu Meranti Metah (Shorea sp.), Institut Pertanian Bogor, Fakultas Matematika dan Ilmu Pengetahuan Alam, Bogor.

[19] Prasetyo, A., dkk., 2011. Adsorpsi Metilen Blue Pada Karbon Aktif dari Ban Bekas dengan Variasi Konsentrasi $\mathrm{NaCl}$ pada Suhu Pengaktifan $600{ }^{\circ} \mathrm{C}$ dan $650{ }^{\circ} \mathrm{C}$, Jurusan Kimia, Fakultas Sains dan Teknologi, Universitas Islam Negeri Maulana Malik Ibrahim, Malang.

[20] Jankowaska, H., Swiatkowski, A., dan Choma, J., 1991, Active Carbon, Ellis Hardwood.

[21] Manocha, S.M., 2003, Porous Carbons, India: Journal Sadhana, Vol 28, parts $1 \& 2$.

[22] Khairunisa, 2008, Pengaruh Konsentrasi Adsorbat, Temperatur, dan Tegangan Permukaan Pada Proses Adsorpsi Gliserol oleh Alumina, Surakarta. 